\title{
INVESTIGATION OF AN AMMONIA-WATER BASED POWER/COOLING COGENERATION SYSTEM USING SENSIBLE WASTE HEAT
}

\author{
Liuli SUN \\ Institute of Engineering Thermophysics, \\ Chinese Academy of Sciences \\ Beijing 100190, China \\ Tel: 86-10-82543031 Fax: 86-10-82622854 \\ E-mail: sunliuli@yahoo.com.cn
}

\author{
Wei HAN \\ Institute of Engineering Thermophysics, \\ Chinese Academy of Sciences \\ Beijing 100190, China \\ Tel: 86-10-82543027 Fax: 86-10-82622854 \\ E-mail: hanwei@mail.etp.ac.cn
}

\author{
Na ZHANG \\ Institute of Engineering \\ Thermophysics, Chinese \\ Academy of Sciences \\ Beijing 100190, China
}

\author{
Noam Lior \\ Department of Mechanical \\ Engineering and Applied Mechanics, \\ University of Pennsylvania \\ Philadelphia, PA 19104-6315, USA
}

\author{
Hongguang JIN \\ Institute of Engineering \\ Thermophysics, Chinese \\ Academy of Sciences \\ Beijing 100190, China
}

\begin{abstract}
In this study, the problem of a parallel connected power and absorption cooling cogeneration system was analyzed and then an improved configuration based on this system was proposed. This system can make cascade utilization of the turbine exhaust heat. By varying turbine outlet pressure, different turbine exhaust vapor temperatures can be obtained, resulting in different amounts of heat that can be recovered in the refrigeration subsystem. Simulation results show that when the turbine outlet pressure in the improved system is 3 bar, 119.6 $\mathrm{kW}$ of heat can be recovered in the refrigeration subsystem, and the total equivalent power output of the improved system is $17.6 \%$ higher than that of the original system. The corresponding equivalent heat-to-power efficiency and thermal energy saving ratio are increased from $16.1 \%$ to $18.9 \%$ and $6.6 \%$ to $26.5 \%$, respectively. When the turbine outlet pressure increases from 1.6 bar to 4 bar, the cooling output increases rapidly, resulting in better performance, and the ratio of power to cooling is in a wide range of 0.19 to 1 . When the turbine outlet pressure is higher than 4 bar, the favorable effect on refrigeration cannot compensate for the adverse effect on power generation, leading to the performance reduction. This study provides a new method for high efficiency utilization of waste heat.
\end{abstract}

\section{INTRODUCTION}

A large amount of mid/low-temperature waste heat is discharged into the environment from industrial plants and processes, resulting to both energy waste and thermal pollution. The recovery and utilization of waste heat is thus of great interest to energy saving and environmental protection.

Refrigeration, power generation and of course direct use of the heat are the main mature methods to recover waste heat. The absorption refrigeration system has been widely used in combined cooling, heating, and power systems to utilize the heat of the engine or gas turbine flue gas, whose operating temperature is usually higher than $300{ }^{\circ} \mathrm{C}[1,2]$. The highest temperature of working fluid in the refrigeration systems is usually below $150{ }^{\circ} \mathrm{C}$. The large temperature difference between the flue gas and the working fluid in the refrigeration system leads to large exergy destruction in the heat recovery process. Rankine power cycles can use steam, organic materials and mixture as working fluids. Steam Rankine Cycles suit large-scale and high-temperature waste heat source. However, Organic Rankine Cycles (ORCs) are more suitable for lowtemperature sensible heat source because of the low boiling temperature and small latent heat of organic fluids [3]. Considering that organic working fluid may decompose at a high temperature [4], the ORCs are suitable for heat sources with temperatures lower than $250{ }^{\circ} \mathrm{C}$. The power cycle with ammonia-water mixture as the working fluid was first investigated in detail by Maloney and Robertson in the 1950s [5], and later ammonia-water based power cycles were studied 
by other researchers $[6,7]$. The use of a mixture with variable evaporation temperature as the working fluid in a power cycle is highly important because it can lead to a better temperature match with the sensible heat source fluid. Consequently, there is less exergy destruction during the heat transfer process. The Kalina cycle, which replaces the conventional condenser with a distillation condensation subordinate system, was invented by Kalina [8] in 1984 as a novel bottoming cycle for the combined cycle. This cycle has been studied for power generation using waste heat [9-11]. However, the complex system makes its practical operation performance far worse than expected [12].

To make better use of the waste heat, research on the integration of power and cooling systems to generate power and cooling simultaneously have been carried out since the 1990s. The working fluid pairs suited for cogeneration systems were reviewed in [13]. Currently, most of the integrated power and cooling systems used ammonia-water mixture as the binary working fluid, because ammonia is a natural material and has good thermodynamic characteristics for both power generation and refrigeration. Goswami et al. [14-23] proposed a power and cooling cogeneration cycle based on the ammonia absorption refrigeration system. A turbine is used to substitute for the condenser and the throttle valve commonly used in refrigeration system to decrease the irreversibility in the throttle process. Amano et al. [24, 25] proposed a hybrid power and refrigeration cycle, which integrated an ammonia-water power cycle and an absorption refrigeration cycle. The power cycle provided stronger solution to the rectifier of the refrigeration cycle to improve the refrigeration performance. Zheng et al. [26] proposed an absorption power and cooling cycle based on the Kalina cycle driven by two isothermal heat sources. A series of devices, including a rectifier, a throttle valve, and an evaporator, were introduced into the primary Kalina cycle to generate cooling using the stream with high-concentration ammonia. Zhang et al. [13, 27-30] proposed two combined refrigeration/power binary fluid systems driven by the flue gas of a gas turbine: a parallel and a series connected system. Wang et al. [31] simplified parallel connected system of [27] to make it usable for flue gas at $300{ }^{\circ} \mathrm{C}$. The high-pressure pump, recuperator, and condenser in the power generation process were eliminated, but the turbine exhaust vapor still reaches $97{ }^{\circ} \mathrm{C}$, resulting in large exergy loss in the absorptioncondensation process. Wang et al. [32] improved their system by introducing an ejector between the rectifier and the condenser of the system. However, the heat rejected by the turbine was still not recovered, and the system exergy efficiency was only improved by $0.6 \%$. Jawahar et al. [33] proposed a power and cooling cogeneration cycle by introducing an expander into the Generator Absorber heat eXchanger cooling cycle (GAX cycle). The expander is placed between the High-Pressure Generator-Absorber-eXchanger (HPGAX) and the absorber. The power and cooling generation processes are parallel, using the same vapor from the HPGAX. However, high ammonia purity of vapor is significant in cooling generation but not necessary in power generation.
The parallel connected system proposed by Zhang et al. in Ref. [13] has been considered as one of the basic system configurations for the cogeneration of power and cooling. However, the temperature of the exhaust vapor from turbine in this cycle is relatively low and it is difficult to use the turbine exhaust heat efficiently in the absorption refrigeration subsystem. In this paper, the authors investigate the problem of energy integration in the parallel system, and then provide a system improvement method for better performance.

\section{THE ORIGINAL PARALLEL POWER/COOLING COGENERATION SYSTEM}

\section{System configuration of the original parallel cogeneration} system

The configuration of the original parallel connected power/cooling cogeneration system proposed in [13] is shown in Figure 1. The strong solution (1) out of the absorber (ABS) is pumped to the rectification pressure (2) and then preheated in a gas heat exchanger (GHEX) by the flue gas. And then the preheated solution (4) is fed into a rectifier (REC1), where it is separated into ammonia-rich vapor (5) for refrigeration and weak solution (12) for power generation. The heat required in the reboiler (REB1) is provided by the flue gas. The ammonia vapor (5) from the top of the rectifier is condensed to liquid state (7) in a condenser (CON1), and then the liquid refrigerant is subcooled (8) in a subcooler (SUBC) and throttled to a low pressure (9) by a throttling valve (TV1) sequentially before it evaporates for refrigeration in the evaporator (EVA). The lowtemperature and low-pressure vapor (10) from the evaporator is sent to the absorber after it cools the liquid ammonia in the subcooler. The weak solution (12) out of the reboiler is pumped to a higher pressure (13) and then vaporized and superheated (14) in the heat recovery vapor generator (HRVG), heated by the high-temperature part of the flue gas. The high-pressure and superheated vapor (14) expands through a turbine (TUR) to generate power. The turbine exhaust vapor (15) is condensed directly (16) in a condenser (CON2) and then the condensed weak solution (16) is pumped (17) to the absorber. In the absorber, the ammonia vapor (11) from the refrigeration subsystem is absorbed by the weak solution (17) to regenerate the strong solution (1) for next cycle. In this system, the power subsystem and refrigeration subsystem are connected in the absorber and rectifier. The flue gas flows through the HRVG, REB1 and HEX1 successively to make cascade utilization of the flue gas heat.

\section{Problem of the original parallel cogeneration system}

The turbine exhaust vapor is ammonia-water binary mixtures, and thus the condensation process has a variable temperature profile and the temperature of the turbine exhaust vapor is much higher than the ambient temperature. In this system, the working fluid in the turbine is set to expand to the lowest possible pressure, which can generate as much power as possible. However, the temperature of the turbine exhaust vapor cannot meet the requirement of the heat source needed in 
the refrigeration subsystem. Therefore, a large amount of turbine exhaust vapor condensation heat is discharged to the environment directly, resulting in energy waste.
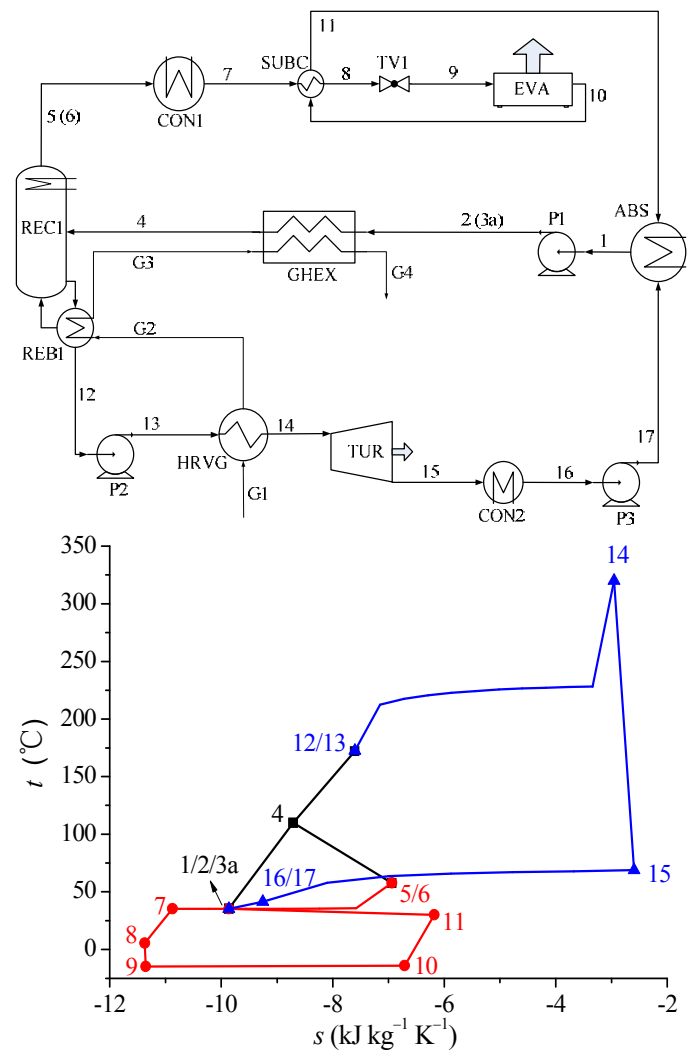

Fig. 1 Flow sheet and $t-s$ diagram of the original parallel cogeneration system

\section{THE IMPROVED POWER/COOLING COGENERATION SYSTEM}

System configuration of the improved cogeneration system

To solve the problem of the original parallel system, the authors make some improvement and present a new system configuration, as shown in Figure 2. Compared with the original system, some new components are added, including a rectifier (REC2), a reboiler (REB2), a heat exchanger (SHEX) and a throttle valve (TV2). The main difference between the original and the improved configuration is in the treatment of the turbine exhaust vapor.

In the original system, the turbine outlet pressure is low, leading to a low temperature of turbine exhaust vapor. Therefore, the condensing heat of the turbine exhaust vapor cannot be used in the refrigeration subsystem and discharged into the environment in CON2. In the improved system, however, the turbine outlet pressure is increased, resulting in a higher turbine exhaust vapor temperature, and can be thus used as the heat source for the refrigeration subsystem. Due to the high temperature in the REB1, the heat required in REB1 is at high temperature, and thus the turbine exhaust vapor cannot be used in it. Another rectifier (REC2) and reboiler (REB2) are therefore added in the improved system to generate more refrigerant (3d) by recovering the condensing heat of the turbine exhaust vapor (15a). In REC2, the concentration difference between the strong solution (3c) and weak solution (3e) is low, thus the temperature requirement of the heat source is not too high, and the turbine exhaust vapor can be used as the heat source in REB2. The weak solution from REB2 (3e) is used to preheat the strong solution feeding to REC2 (3b). If the turbine outlet pressure is higher than the absorber pressure, the vapor and liquid mixture (15b) from REB2 can be mixed together with the weak solution (3f) and then throttled by the TV2. If the turbine outlet pressure is lower than the absorber pressure, the vapor and liquid mixture (15b) from REB2 should be condensed completely in CON2 (16) and then pumped (17) to the absorber by P3.

\section{Features of the improved cogeneration system}

Compared with the original cogeneration system, the improved system has two main new features.

First, the condensing heat of the turbine exhaust vapor is recovered and used for generating more refrigerant. Different from the original system, the working fluid in the turbine is set to expand to a proper pressure. The temperature of the turbine exhaust vapor is therefore high and the condensing heat of the turbine exhaust vapor can be used in the refrigeration subsystem through REB2.

Second, the ratio of power and cooling output can be varied by changing the turbine outlet pressure. If the turbine outlet pressure is set to low, more heat is used to generate power and less of the condensing heat of the turbine exhaust vapor can be used in the refrigeration subsystem; hence less cooling can be produced. If the turbine outlet pressure is set to be high, the power generated in the turbine is lower and more heat can be used for refrigeration and thus the cooling output will be increased.

\section{EVALUATION CRITERIA AND THE REFERENCE SYSTEMS}

In this study, equivalent heat-to-power efficiency $\left(\eta_{\mathrm{W} \text {,eq }}\right)$ and Thermal Energy Saving Ratio (TESR) were used to evaluate the system performance.

The equivalent heat-to-power efficiency is based on the first law of thermodynamics but considers the quality difference between the power and cooling outputs. The cooling output is converted into its equivalent power output using a practically achievable Coefficient Of Performance of a compression refrigeration system $\left(\mathrm{COP}_{\mathrm{C}}\right)$ [16]. The equivalent heat-to-power efficiency is expressed as the ratio of power output (including the net power output of the system and the equivalent power output of the cooling effect) to the energy input to the system:

$$
\eta_{\mathrm{W}, \text { eq }}=\frac{W_{\text {eq }}}{Q_{\mathrm{f}}}=\frac{W_{\text {net }}+Q_{\mathrm{C}} / \mathrm{COP}_{\mathrm{C}}}{Q_{\mathrm{f}}}
$$



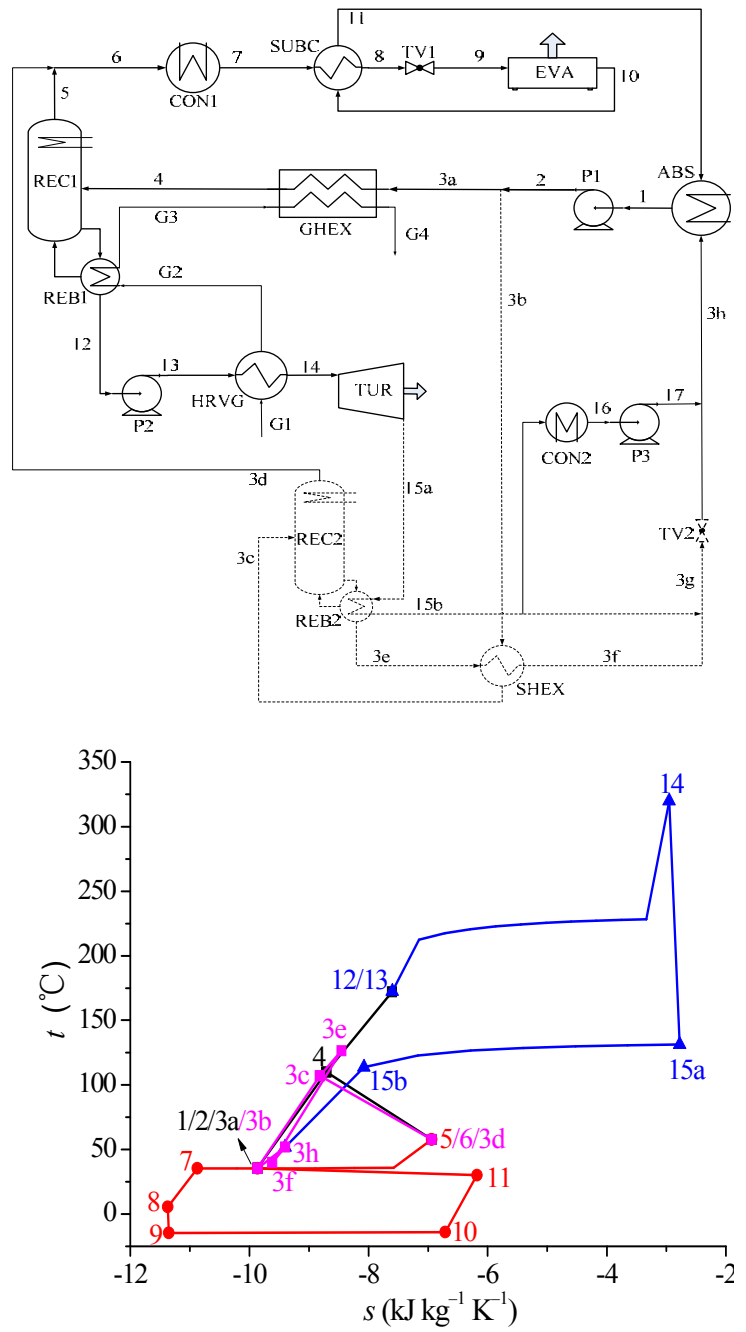

Fig. 2 Flow sheet and $t-s$ diagram of the improved cogeneration system proposed in this study

where $W_{\text {net }}$ represents the equivalent power output; $W_{\text {net }}$ represents the net power output, which is the power output from the turbine reduced by the power consumed by the pumps $\left(W_{\text {net }}=W_{\mathrm{TUR}}-W_{\mathrm{HP}}-W_{\mathrm{LP}}\right) ; Q_{\mathrm{C}}$ represents cooling output; $\mathrm{COP}_{\mathrm{C}}$ is the coefficient of performance of the compression refrigerator; $Q_{\mathrm{f}}$ represents the heat supplied to the system, which is calculated by

$$
Q_{\mathrm{f}}=m_{\mathrm{G} 1}\left(h_{\mathrm{G} 1}-h_{0}\right)
$$

where $m_{\mathrm{G} 1}$ is the mass flow rate of flue gas; $h_{\mathrm{G} 1}$ and $h_{0}$ refer to the specific enthalpies of the flue gas at the temperature and pressure at which it enters the system and at the ambient temperature and pressure, respectively.

Other criteria are used to compare the primary energy required by the proposed system and that by the reference systems to produce the same energy output $[34,35]$. The thermal energy saving ratio is defined as the energy input difference, in terms of waste heat required, between the reference systems and proposed system divided by the energy input of the reference systems under the assumption of the same power and cooling outputs:

$$
T E S R=\frac{Q_{\mathrm{f}, \text { ref }}-Q_{\mathrm{f}}}{Q_{\mathrm{f}, \mathrm{ref}}}
$$

where $Q_{\mathrm{f} \text {,ref }}$ and $Q_{\mathrm{f}}$ are the heat input to the reference and the integrated systems, respectively.

In this study, the reference systems include separate Rankine and absorption refrigeration cycles, as shown in Figure 3. Given that the power capacity of the integrated system is relatively small, a basic Steam Rankine Cycle (SRC) is adopted as the reference power generation system. Figure 3(a) shows the configuration of the SRC. The heat of flue gas (G1) is recovered in a Heat Recovery Vapor Generator (HRVG) to generate superheated steam (3) for a steam turbine (TUR) to produce power. The steam (4) exhausted from the turbine is condensed, and the condensed water (1) is pumped back to the HRVG (2). A single-effect Ammonia Absorption Refrigeration Cycle (AARC) is set as the reference refrigeration system, as shown in Figure 3(b). The strong solution (1) is first pressurized (2) and preheated (3) in the solution heat exchanger (SHEX) by a weak solution (10), after which it flows into the rectifier (REC). The flue gas (G1) is introduced to a reboiler (REB) of the rectifier to generate pure ammonia vapor (4) and weak solution (10). The ammonia vapor (4) is condensed (5) in a condenser $(\mathrm{CON})$ and then subcooled (6) in a subcooler (SUBC). The liquid ammonia (6) is throttled to a low pressure (7) by a Throttle Valve 1 (TV1), after which it evaporates for refrigeration (8) in an evaporator (EVA). The low-pressure ammonia vapor (9) is then absorbed by a stream of throttled weak solution (12) to regenerate the strong solution (1).

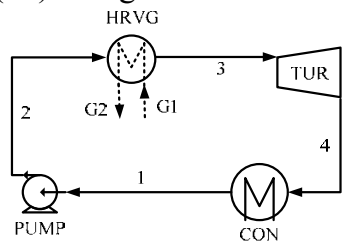

(a) Steam Rankine Cycle

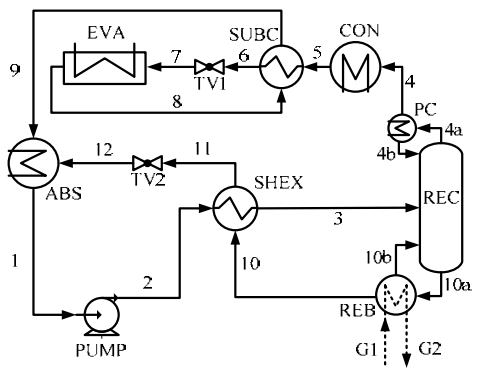

(b) Ammonia Absorption Refrigeration Cycle

Fig. 3 Schematic configurations of the reference systems. 


\section{SYSTEM SIMULATION AND RESULTS ANALYSIS}

\section{System modeling and model validation}

In this study, simulations of both the proposed and reference systems were performed using the commercial software Aspen Plus [36], which contains various models that can be used to develop power generation and refrigeration processes. Every model is based on mass balance and energy balance, with a default relative convergence error tolerance of $0.01 \%$. The modified Peng-Robinson equation of state was used to calculate the thermodynamic properties of the ammonia-water mixture. The original built-in Peng-Robinson equation in the Aspen Plus software was modified based on the vapor-liquid equilibrium state of the ammonia-water system published by the International Institute of Refrigeration [37]. The thermodynamic consistency test was passed and the mean relative deviation and the maximum relative deviation on pressure were $0.694 \%$ and $2.065 \%$, respectively.

Each component in the original system, the improved system and the reference separate systems, can be considered as a control volume with inlet and outlet of fluids, heat, and work. The basic equations are applied to establish the thermodynamic model, including mass conservation equation, ammonia mass conservation equation, and energy conservation equation, as expressed by Eqs. (4) to (6).

$$
\begin{aligned}
& \sum m_{\text {in }}=\sum m_{\text {out }} \\
& \sum m_{\text {in }} x_{\text {in }}=\sum m_{\text {out }} x_{\text {out }} \\
& \sum m_{\text {in }} h_{\text {in }}-\sum m_{\text {out }} h_{\text {out }}=\sum W-\sum Q
\end{aligned}
$$

Data from the available literature were used to validate the computation model in this study, which was used to run under the same operating conditions used in the corresponding references. The SRC computation was validated by the data in $[29,30]$, and the AARC by the data in [38]. The main operating conditions and comparison results are summarized in Tables 1 and 2. Data in Tables 1 and 2 show that the relative errors of energy efficiency of the SRC and the Coefficient Of Performance of the AARC $\left(\mathrm{COP}_{\mathrm{A}}\right)$ are $0.7 \%$ and $1.6 \%$, respectively. This comparison indicates that the $\mathrm{SRC}$ and the AARC model in the present study are reliable and that the simulation results can provide useful information.

Table 1 Model validation for the SRC.

\begin{tabular}{|c|c|c|}
\hline Items & $\begin{array}{l}\text { Present } \\
\text { study }\end{array}$ & Ref. [38] \\
\hline $\begin{array}{l}\text { Concentration difference between } \\
\text { the strong and weak solutions }\end{array}$ & 0.100 & 0.100 \\
\hline $\begin{array}{l}\text { Condensation/evaporation } \\
\text { pressure (bar) }\end{array}$ & $15.56 / 2.45$ & $15.56 / 2.45$ \\
\hline $\begin{array}{l}\text { Effectiveness of solution heat } \\
\text { exchanger/subcooler }(\%)\end{array}$ & $100 / 95$ & $100 / 95$ \\
\hline Isentropic efficiency of pump (\%) & 50 & 50 \\
\hline Temperature of generator $\left({ }^{\circ} \mathrm{C}\right)$ & 133.9 & 130.3 \\
\hline Temperature of condenser $\left({ }^{\circ} \mathrm{C}\right)$ & 40.3 & 40.0 \\
\hline Temperature of absorber $\left({ }^{\circ} \mathrm{C}\right)$ & 37.9 & 40.0 \\
\hline Temperature of evaporator $\left({ }^{\circ} \mathrm{C}\right)$ & -13.8 & -14.1 \\
\hline $\begin{array}{l}\text { Mass flow rate of strong solution } \\
\left(\mathrm{kg} \mathrm{s}^{-1}\right)\end{array}$ & 1 & 1 \\
\hline $\begin{array}{l}\text { Mass flow rate of refrigerant }(\mathrm{kg} \\
\left.\mathrm{s}^{-1}\right)\end{array}$ & 0.137 & 0.137 \\
\hline $\begin{array}{l}\text { Ammonia mass concentration of } \\
\text { refrigerant }(-)\end{array}$ & 0.9998 & 0.9996 \\
\hline Cooling output (kW) & 162.1 & 162.0 \\
\hline Heat load of the reboiler $(\mathrm{kW})$ & 263.4 & 267.9 \\
\hline Power load of the pump (kW) & 3.22 & 3 \\
\hline $\mathrm{COP}_{\mathrm{A}} *$ & 0.607 & 0.598 \\
\hline Relative error of the $\mathrm{COP}_{\mathrm{A}}(\%)$ & 1.6 & \\
\hline
\end{tabular}

\begin{tabular}{lll}
\hline Items & $\begin{array}{l}\text { Present } \\
\text { study }\end{array}$ & $\begin{array}{l}\text { Refs. } \\
{[29,30]}\end{array}$ \\
\hline Turbine inlet temperature $\left({ }^{\circ} \mathrm{C}\right)$ & 450 & 450 \\
Turbine inlet/outlet pressure (bar) & $34.92 / 0.06$ & - \\
Isentropic efficiency of turbine $(\%)$ & 87 & 87 \\
Cooling water temperature $\left({ }^{\circ} \mathrm{C}\right)$ & 30 & 30 \\
Energy efficiency* $(\%)$ & 21.65 & 21.5 \\
Relative error of energy efficiency $(\%)$ & 0.7 & \\
\hline *Energy efficiency of the SRC is the ratio of the net power & \\
output to the heat input to the system.
\end{tabular}

Table 2 Model validation for the AARC.

\section{Basic assumptions for the simulation}

The following are the main basic assumptions of the proposed in the simulation.

(1) The system runs under steady conditions.

(2) The evaporation temperature in the evaporator $t_{\mathrm{EVA}}$ is about $-15^{\circ} \mathrm{C}$, and the average cooling temperature $t_{\mathrm{C}}$ is $-10{ }^{\circ} \mathrm{C}$ considering a temperature difference of $5^{\circ} \mathrm{C}$.

(3) The isentropic efficiencies of the pumps and turbine are 0.75 and 0.85 , respectively.

(4) The minimal temperature differences are $15^{\circ} \mathrm{C}$ for gasliquid heat exchangers (HRVG and GHEX), and no less than $5{ }^{\circ} \mathrm{C}$ for liquid-liquid heat exchangers (such as SHEX1, SHEX2, condenser and absorber). The preheated strong solution is not allowed to vaporize in the solution heat exchanger.

(5) The pressure loss ratio of each component is $3 \%$.

(6) The ammonia mass concentration of the refrigerant is 0.998.

\section{Simulation results in the base case}

In the base case, the flue gas temperature and cooling water temperature are $350{ }^{\circ} \mathrm{C}$ and $30{ }^{\circ} \mathrm{C}$, respectively. Table 3 summarizes the parameters of the main streams in both the original and improved systems in the base case. The parameters of streams 1 to 14 in both the original and improved systems 
are same. The difference of the two systems lies in the treatment process of the turbine outlet vapor.

Tables 4 and 5 summarize the load of the main components in the system and the performance comparison of the original and improved systems. It can be seen from the tables that, the turbine outlet pressure of the original system is $0.3 \mathrm{bar}$, the net power output is $39.1 \mathrm{~kW} .0 .0235 \mathrm{~kg} \mathrm{~s}^{-1}$ of refrigerant is produced in the rectifier, generating $28.2 \mathrm{~kW}$ of cooling. The total equivalent power output is $49.5 \mathrm{~kW}$, and the equivalent heat-to-power efficiency $\left(\eta_{\mathrm{W} \text {,eq }}\right)$ is $16.1 \%$. In the improved system, the turbine outlet pressure is $3 \mathrm{bar}$, thus the net power output is reduced to $21.4 \mathrm{~kW}$. The temperature and dryness of the turbine exhaust vapor are however much higher than those in the original system, so that $119.6 \mathrm{~kW}$ of the condensing heat of the turbine exhaust vapor is recovered in REB2, producing $0.0594 \mathrm{~kg} \mathrm{~s}^{-1}$ of refrigerant from REC2. The total refrigerant generation rate from REC1 and REC2 is thus $0.0829 \mathrm{~kg} \mathrm{~s}^{-1}$, and the cooling output of the improved system is $99.4 \mathrm{~kW}$.

Table 3 Parameters of the main points in the original and improved systems.

\begin{tabular}{|c|c|c|c|c|c|c|c|c|c|c|}
\hline & \multicolumn{2}{|c|}{$t\left({ }^{\circ} \mathrm{C}\right)$} & \multicolumn{2}{|c|}{$p$ (bar) } & \multicolumn{2}{|c|}{$x$} & \multicolumn{2}{|c|}{$m\left(\mathrm{~kg} \mathrm{~s}^{-1}\right)$} & \multicolumn{2}{|c|}{$V F$} \\
\hline & $\begin{array}{c}\text { origina } \\
1 \\
\end{array}$ & $\begin{array}{c}\text { improve } \\
\mathrm{d}\end{array}$ & $\begin{array}{c}\text { origina } \\
1 \\
\end{array}$ & $\begin{array}{c}\text { improve } \\
\mathrm{d}\end{array}$ & $\begin{array}{c}\text { origina } \\
1 \\
\end{array}$ & $\begin{array}{c}\text { improve } \\
\mathrm{d}\end{array}$ & $\begin{array}{c}\text { origina } \\
1 \\
\end{array}$ & $\begin{array}{c}\text { improve } \\
\mathrm{d}\end{array}$ & $\begin{array}{c}\text { origina } \\
1 \\
\end{array}$ & $\begin{array}{c}\text { improve } \\
\mathrm{d}\end{array}$ \\
\hline 1 & 35.3 & 35.3 & 2.23 & 2.23 & 0.37 & 0.37 & 0.0799 & 0.5491 & 0 & 0 \\
\hline 2 & 35.5 & 35.5 & 14.79 & 14.79 & 0.37 & 0.37 & 0.0799 & 0.5491 & 0 & 0 \\
\hline $3 a$ & 35.5 & 35.5 & 14.79 & 14.79 & 0.37 & 0.37 & 0.0799 & 0.0799 & 0 & 0 \\
\hline 4 & 110.0 & 110.0 & 14.35 & 14.35 & 0.37 & 0.37 & 0.0799 & 0.0799 & 0.035 & 0.035 \\
\hline 5 & 57.7 & 57.7 & 13.92 & 13.92 & 0.998 & 0.998 & 0.0235 & 0.0235 & 1 & 1 \\
\hline 6 & 57.7 & 57.7 & 13.92 & 13.92 & 0.998 & 0.998 & 0.0235 & 0.0830 & 1 & 1 \\
\hline 7 & 35.3 & 35.3 & 13.50 & 13.50 & 0.998 & 0.998 & 0.0235 & 0.0830 & 0 & 0 \\
\hline 8 & 5.6 & 5.6 & 13.50 & 13.50 & 0.998 & 0.998 & 0.0235 & 0.0830 & 0 & 0 \\
\hline 9 & -14.6 & -14.6 & 2.37 & 2.37 & 0.998 & 0.998 & 0.0235 & 0.0830 & 0.070 & 0.070 \\
\hline 10 & -14.0 & -14.0 & 2.30 & 2.30 & 0.998 & 0.998 & 0.0235 & 0.0830 & 0.963 & 0.963 \\
\hline 11 & 30.0 & 30.0 & 2.30 & 2.30 & 0.998 & 0.998 & 0.0235 & 0.0830 & 1 & 1 \\
\hline 12 & 172.1 & 172.1 & 13.92 & 13.92 & 0.108 & 0.108 & 0.0564 & 0.0564 & 0 & 0 \\
\hline 13 & 172.5 & 172.5 & 30.93 & 30.93 & 0.108 & 0.108 & 0.0564 & 0.0564 & 0 & 0 \\
\hline 14 & 320.0 & 320.0 & 30.00 & 30.00 & 0.108 & 0.108 & 0.0564 & 0.0564 & 1 & 1 \\
\hline 15 & 68.9 & - & 0.30 & - & 0.108 & - & 0.0564 & - & 0.894 & - \\
\hline 16 & 41.4 & - & 0.294 & - & 0.108 & - & 0.0564 & - & 0 & - \\
\hline 17 & 41.4 & - & 2.30 & - & 0.108 & - & 0.0564 & - & 0 & - \\
\hline $\begin{array}{c}15 \mathrm{a} \\
15\end{array}$ & - & 131.3 & - & 3.00 & - & 0.108 & - & 0.0564 & - & 0.968 \\
\hline $\mathrm{b}$ & - & 113.6 & - & 3.00 & - & 0.108 & - & 0.0564 & - & 0.043 \\
\hline $3 b$ & - & 35.5 & - & 14.75 & - & 0.37 & - & 0.4691 & - & 0 \\
\hline $3 c$ & - & 107.2 & - & 14.35 & - & 0.37 & & 0.4691 & - & 0.013 \\
\hline $3 d$ & - & 57.7 & - & 13.92 & - & 0.998 & - & 0.0594 & - & 1 \\
\hline $3 e$ & - & 126.3 & - & 13.92 & - & 0.279 & - & 0.4097 & - & 0 \\
\hline $3 \mathrm{f}$ & - & 40.0 & - & 13.92 & - & 0.279 & - & 0.4097 & - & 0 \\
\hline $3 g$ & - & 51.8 & - & 3.00 & - & 0.258 & - & 0.4661 & - & 0 \\
\hline $3 \mathrm{~h}$ & - & 51.8 & - & 2.30 & - & 0.258 & - & 0.4661 & - & 0 \\
\hline G1 & 350.0 & 350.0 & 1 & 1 & - & - & 0.9306 & 0.9306 & 1 & 1 \\
\hline $\mathrm{G} 2$ & 216.2 & 216.2 & 1 & 1 & - & - & 0.9306 & 0.9306 & 1 & 1 \\
\hline G3 & 159.3 & 159.3 & 1 & 1 & - & - & 0.9306 & 0.9306 & 1 & 1 \\
\hline G4 & 125.5 & 125.5 & 1 & 1 & - & - & 0.9306 & 0.9306 & 1 & 1 \\
\hline
\end{tabular}


The total equivalent power output is $58.2 \mathrm{~kW}(17.6 \%$ higher than that of the original system), and the equivalent heat-topower efficiency $\left(\eta_{\mathrm{W} \text {,eq }}\right)$ is $18.9 \%$.

On the whole, the improved system generates $17.7 \mathrm{~kW}$ less power and $71.2 \mathrm{~kW}$ more cooling than the original system. The total equivalent power output of the improved system is $8.7 \mathrm{~kW}$ higher than that of the original system, leading to an increase of $17.5 \%$ in the equivalent heat-to-power efficiency.

Table 4 The load of each component of the original and improved systems

\begin{tabular}{|c|c|c|}
\hline & original & improved \\
\hline Flue gas temperature, $t_{\mathrm{G} 1}\left({ }^{\circ} \mathrm{C}\right)$ & 350 & 350 \\
\hline Heat input with the flue gas, $Q_{\text {in }}(\mathrm{kW})$ & 307.6 & 307.6 \\
\hline $\begin{array}{l}\text { Mass flow rate of the strong solution, } m_{1} \\
\left(\mathrm{~kg} \mathrm{~s}^{-1}\right)\end{array}$ & 0.0799 & 0.5491 \\
\hline $\begin{array}{l}\text { Mass flow rate of the feed stream of } \\
\text { REC } 1, m_{4}\left(\mathrm{~kg} \mathrm{~s}^{-1}\right)\end{array}$ & 0.0799 & 0.0799 \\
\hline $\begin{array}{l}\text { Mass flow rate of the feed stream of } \\
\text { REC2, } m_{3 \mathrm{c}}\left(\mathrm{kg} \mathrm{s}^{-1}\right)\end{array}$ & - & 0.4691 \\
\hline $\begin{array}{l}\text { Mass flow rate of the working fluid for } \\
\text { power generation, } m_{12}\left(\mathrm{~kg} \mathrm{~s}^{-1}\right)\end{array}$ & 0.0564 & 0.0564 \\
\hline $\begin{array}{l}\text { Mass flow rate of the refrigerant from } \\
\text { REC } 1, m_{5}\left(\mathrm{~kg} \mathrm{~s}^{-1}\right)\end{array}$ & 0.0235 & 0.0235 \\
\hline $\mathrm{REC} 2, m_{3 \mathrm{~d}}\left(\mathrm{~kg} \mathrm{~s}^{-1}\right)$ & - & 0.0594 \\
\hline Turbine outlet pressure, $p_{15} / p_{15 \mathrm{a}}$ (bar) & 0.3 & 3 \\
\hline Turbine exhaust temperature, $t_{15} / t_{15 \mathrm{a}}\left({ }^{\circ} \mathrm{C}\right)$ & 68.9 & 131.3 \\
\hline $\begin{array}{l}\text { Vapor fraction of turbine exhaust vapor, } \\
V F_{15} / V F_{15} \text { a }\end{array}$ & 0.894 & 0.968 \\
\hline Heat load of HRVG, $Q_{\mathrm{HRVG}}(\mathrm{kW})$ & 130.6 & 130.6 \\
\hline Heat load of REB1, $Q_{\mathrm{REB} 1}(\mathrm{~kW})$ & 54.5 & 54.5 \\
\hline Heat load of HEX1, $Q_{\mathrm{HEX} 1}(\mathrm{~kW})$ & 32.2 & 32.2 \\
\hline Heat load of CON1, $Q_{\mathrm{CON} 1}(\mathrm{~kW})$ & 28.7 & 101.3 \\
\hline Heat load of SUBC, $Q_{\mathrm{SUBC}}(\mathrm{kW})$ & 3.5 & 12.2 \\
\hline Heat load of ABS, $Q_{\mathrm{ABS}}(\mathrm{kW})$ & 40.8 & 166.9 \\
\hline Power generated by TUR, $W_{\mathrm{TUR}}(\mathrm{kW})$ & 39.4 & 22.7 \\
\hline Heat load of CON2, $Q_{\mathrm{CON} 2}(\mathrm{~kW})$ & 126.5 & - \\
\hline $\begin{array}{l}\text { Power load of pumps, } W_{\mathrm{P} 1}+W_{\mathrm{P} 2}+W_{\mathrm{P} 3} \\
(\mathrm{~kW})\end{array}$ & 0.35 & 1.29 \\
\hline Heat load of REB2, $Q_{\mathrm{REB} 2}(\mathrm{~kW})$ & - & 119.6 \\
\hline Heat load of HEX2, $Q_{\mathrm{HEX} 2}(\mathrm{~kW})$ & - & 169.5 \\
\hline
\end{tabular}

Table 5 The performance comparison of the original and improved systems

\begin{tabular}{|c|c|c|}
\hline & original & improved \\
\hline Net power output, $W_{\text {net }}(\mathrm{kW})$ & 39.1 & 21.4 \\
\hline Cooling output, $Q_{\mathrm{C}}(\mathrm{kW})$ & 28.2 & 99.4 \\
\hline $\begin{array}{l}\text { Equivalent power of the cooling } \\
\text { output*, } W_{\mathrm{eqC}}(\mathrm{kW})\end{array}$ & 10.4 & 36.8 \\
\hline $\begin{array}{l}\text { Total equivalent power output, } W_{\text {eq }} \\
(\mathrm{kW})\end{array}$ & 49.5 & 58.2 \\
\hline $\begin{array}{l}\text { Equivalent heat-to-power efficiency, } \\
\eta_{\mathrm{W}, \mathrm{eq}}(\%)\end{array}$ & 16.1 & 18.9 \\
\hline Energy input to the SRC (kW) & 249.2 & 136.4 \\
\hline Energy input to the AARC $(\mathrm{kW})$ & 80.0 & 281.8 \\
\hline Thermal energy saving ratio, TESR (\%) & 6.6 & 26.5 \\
\hline
\end{tabular}

\section{Effect of turbine outlet pressure}

In this system, the turbine outlet pressure is a key parameter affecting the power and cooling outputs and ratio, and the system performance. The temperature of REB2 is about $108^{\circ} \mathrm{C}$, so heat with a temperature higher than $113{ }^{\circ} \mathrm{C}$ can be used in the REB2 when a minimum temperature difference of $5{ }^{\circ} \mathrm{C}$ is considered. The turbine exhaust temperature $t_{15 \mathrm{a}}$ varies with the turbine outlet pressure $p_{15 \mathrm{a}}$, which leads to different amounts of heat that can be used in REB2 $\left(Q_{\mathrm{REB} 2}\right)$. The ammonia concentration of turbine exhaust vapor is 0.108 , and $t_{15 \mathrm{a}}$ is higher than $113{ }^{\circ} \mathrm{C}$ when $p_{15 \mathrm{a}}$ is higher than 1.6 bar. Figures 4 and 5 show the system output and performance when $p_{15 \mathrm{a}}$ varies in the range of 1.6 bar to 10 bar. It should be noted that, the pressure in absorber is 2.23 bar. When $p_{15 a}$ is lower than the absorber pressure, the turbine exhaust should be completely condensed in CON2 and pumped by P3 to absorber after releasing the high-temperature part of condensing heat in REB2. When $p_{15 \mathrm{a}}$ is higher than the absorber pressure, the turbine exhaust vapor mixes with the weak solution (3f) from SHEX2 to form stream $3 \mathrm{~g}$, which is throttled by TV2 before entering absorber.

Figures 4 and 5 show the effect of $p_{15 a}$ on the system output and performance. When $p_{15 \mathrm{a}}$ increases from 1.6 bar to $10 \mathrm{bar}$, the power output $W_{\text {net }}$ decreases smoothly and the cooling output $Q_{\mathrm{C}}$ increases first rapidly and then slowly. In this range, the equivalent power output $W_{\text {eq }}$ shows a trend of first increases and then decreases. Figure 6 shows the variation of $Q_{\text {REB2 }}$ at different $p_{15 \mathrm{a}}$. It can be seen from Figure 6 that when $p_{15 \mathrm{a}}$ rises from 1.6 bar to 4 bar, the amount of condensing heat that can be used in REB2 $Q_{\text {REB2 }}$ increases rapidly to $127 \mathrm{~kW}$, thus $Q_{\mathrm{C}}$ rises from $28.2 \mathrm{~kW}$ to $103 \mathrm{~kW}$, and $W_{\text {net }}$ decreases from 27.5 $\mathrm{kW}$ to $19.9 \mathrm{~kW}$. The corresponding $W_{\text {eq }}$ and $\eta_{\mathrm{W} \text {,eq }}$ increase to $58.1 \mathrm{~kW}$ and $18.7 \%$, respectively. The ratio of power to cooling is 0.19 . 
When $p_{15 \mathrm{a}}$ is 4 bar, the saturated liquid temperature of turbine exhaust vapor $t_{15 \mathrm{a} 0}$ is $113{ }^{\circ} \mathrm{C}$, as shown in Figure 6. This means all the condensing heat of turbine exhaust vapor can be used in REB2. When $p_{15 \mathrm{a}}$ increases from 4 bar to 10 bar, $Q_{\mathrm{REB} 2}$ increases very slowly, for only some additional sensible heat of condensed solution can be recovered during this range. In this condition, the increase in $Q_{\mathrm{C}}$ is very slow, and the equivalent power of the increased cooling output cannot make up the decrease of the power output, resulting in a lower $W_{\text {eq }}$ and $\eta_{\mathrm{W}, \text { eq. }}$. As can be seen from Figures 4 and 5, when $p_{15 \mathrm{a}}$ is $10 \mathrm{bar}$, the total $W_{\text {eq }}$ is $51.6 \mathrm{~kW}$; the corresponding $\eta_{\mathrm{W} \text {,eq }}$ is $16.8 \%$ and the corresponding ratio of power to cooling is 0.11 .

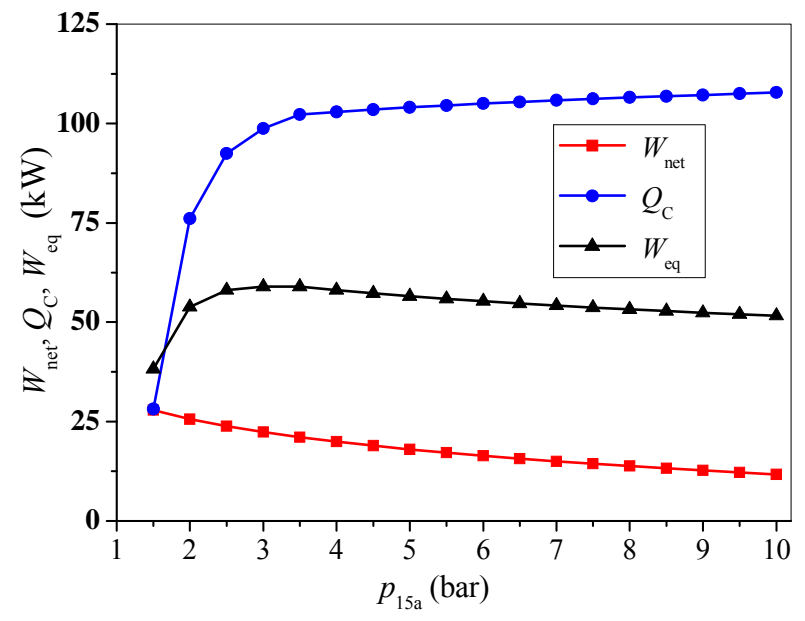

Fig. 4 Effect of $p_{15 \mathrm{a}}$ on $W_{\text {net }}, Q_{\mathrm{C}}$ and $W_{\text {eq }}$

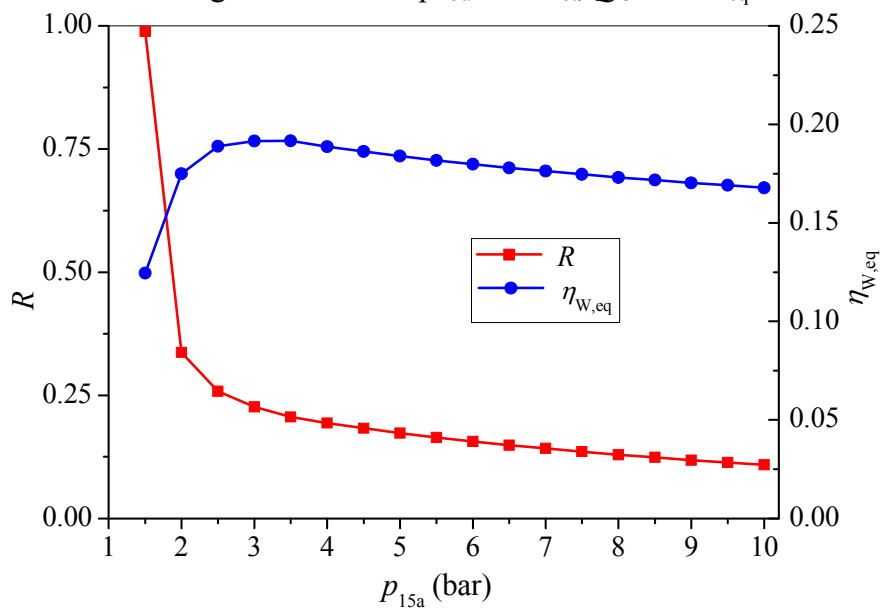

Fig. 5 Effect of $p_{15 \mathrm{a}}$ on $R$ and $\eta_{\mathrm{w}, \mathrm{eq}}$

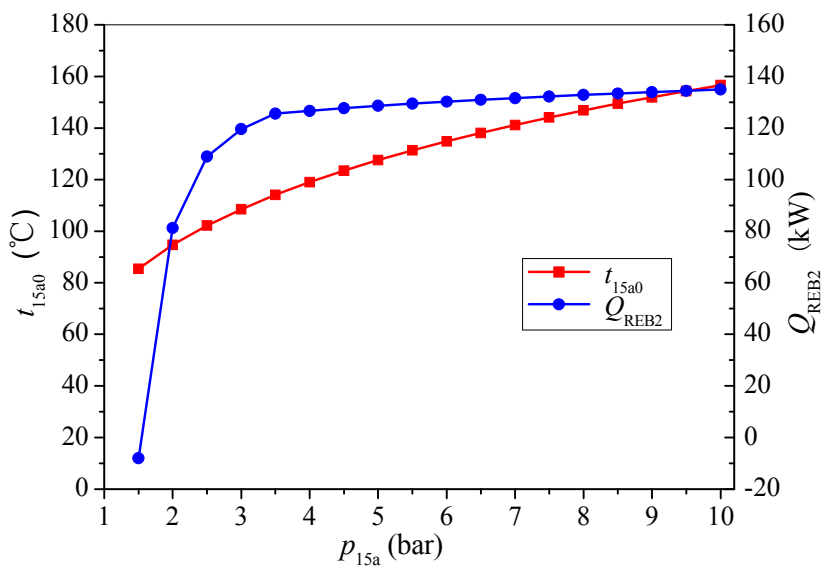

Fig. 6 Effect of $p_{15 \mathrm{a}}$ on $t_{15 \mathrm{a} 0}$ and $Q_{\mathrm{REB} 2}$

\section{CONCLUSIONS}

In this study, the parallel connected power and cooling cogeneration system proposed in [13] was analyzed and then a new improved configuration based on this system was proposed. In the original parallel cogeneration system, the heat of flue gas can be utilized in a cascade way, but there is a main problem in the internal energy integration of the system: the turbine exhaust heat is rejected to the environment directly, leading to a large amount of heat waste. The improved system proposed in this paper can make cascade utilization of the turbine exhaust heat, and by varying the turbine outlet pressure, different turbine exhaust vapor temperature can be obtained, resulting in different amounts of heat that can then be used by the refrigeration subsystem. Simulation results show that when $p_{15 \mathrm{a}}$ in the improved system is $3 \mathrm{bar}, 119.6 \mathrm{~kW}$ of heat can be recovered in REB2 for refrigeration, and the total equivalent power output of the improved system is $17.6 \%$ higher than that of the original system. The corresponding $\eta_{\mathrm{W} \text {,eq }}$ and TESR are increased from $16.1 \%$ to $18.9 \%$ and $6.6 \%$ to $26.5 \%$, respectively. When $p_{15 \mathrm{a}}$ is increased from $1.6 \mathrm{bar}$ to $4 \mathrm{bar}$, the cooling output increases rapidly, resulting in higher $W_{\text {eq }}$ and $\eta_{\mathrm{W}, \mathrm{eq}}$, and the ratio of power to cooling is in a wide range of 0.19 to1. When $p_{15 \mathrm{a}}$ is higher than 4 bar, the favourable contribution by producing refrigeration cannot compensate for the adverse effect on power generation, leading to gradually decrease of $W_{\text {eq }}$ and $\eta_{\mathrm{w} \text {,eq }}$. This study proposes and quantifies a new method for the high efficient utilization of waste heat.

\section{NOMENCLATURE}

$\mathrm{COP}_{\mathrm{A}}$ Coefficient Of Performance of absorption

$\mathrm{COP}_{\mathrm{C}} \quad$ Coefficient Of Performance of compression refrigeration cycle (-)

$m \quad$ Mass flow rate $\left(\mathrm{kg} \mathrm{s}^{-1}\right)$

$p \quad$ Pressure (bar)

$Q \quad$ Heat transfer rate $(\mathrm{kW})$ 


\begin{tabular}{|c|c|}
\hline$s$ & Specific entropy $\left(\mathrm{kJ} \mathrm{kg}^{-1} \mathrm{~K}^{-1}\right)$ \\
\hline$t$ & Temperature $\left({ }^{\circ} \mathrm{C}\right)$ \\
\hline$T$ & Temperature $(\mathrm{K})$ \\
\hline TESR & Thermal Energy Saving Ratio (-) \\
\hline$V F$ & Vapor Fraction (-) \\
\hline$W$ & Power load $(\mathrm{kW})$ \\
\hline$W_{\text {net }}$ & Net power output $(\mathrm{kW})$ \\
\hline$W_{\text {eq }}$ & Equivalent power output $(\mathrm{kW})$ \\
\hline$x$ & Ammonia mass concentration (-) \\
\hline$\eta_{\mathrm{W}, \mathrm{eq}}$ & Equivalent heat-to-power efficiency (\%) \\
\hline \multicolumn{2}{|c|}{ Abbreviations: } \\
\hline AARC & Ammonia Absorption Refrigeration Cycle \\
\hline $\mathrm{ABS}$ & Absorber \\
\hline $\mathrm{CON}$ & Condenser \\
\hline CON1 & Condenser 1 \\
\hline CON2 & Condenser 2 \\
\hline EVA & Evaporator \\
\hline$f$ & Engine flue gas for the cogeneration systen \\
\hline f,ref & Engine flue gas for the reference systems \\
\hline GHEX & Gas Heat EXchanger \\
\hline HRVG & Heat Recovery Vapor Generator \\
\hline P1 & Pump 1 \\
\hline $\mathrm{P} 2$ & Pump 2 \\
\hline P3 & Pump 3 \\
\hline$R$ & Ratio of power to cooling \\
\hline REB1 & Reboiler 1 \\
\hline REB2 & Reboiler 2 \\
\hline REC1 & Rectifier 1 \\
\hline REC2 & Rectifier 2 \\
\hline SHEX & Solution Heat EXchanger \\
\hline $\mathrm{SRC}$ & Steam Rankine Cycle \\
\hline SUBC & Subcooler \\
\hline TUR & Turbine \\
\hline TV1 & Throttle Valve 1 \\
\hline TV2 & Throttle Valve 2 \\
\hline 0 & Ambient condition \\
\hline $1,2 \ldots 27$ & States on the system configuration \\
\hline G1,G2,G3 & Engine flue gas \\
\hline
\end{tabular}

\section{ACKNOWLEDGMENTS}

The authors gratefully acknowledge the support of the National Natural Science Foundation of China (Grant No. 51176185) and the National Basic Research Program of China (973 Program) (Grant No. 2010CB227304).

\section{REFERENCES}

[1] Colonna $\mathrm{P}$, Gabrielli S. Industrial trigeneration using ammonia-water absorption refrigeration systems (AAR). Applied Thermal Engineering 2003; 23: 381-96.
[2] Rocha MS, Andreos R, Simões-Moreira JR. Performance tests of two small trigeneration pilot plants. Applied Thermal Engineering 2012; 41: 84-91.

[3] Borsukiewicz-Gozdur A, Nowak W. Comparative Analysis of Natural and Synthetic Refrigerants in Application to Low Temperature Clausius-Rankine Cycle. Energy 2007; 32: 344-52.

[4] Hung TC, Shai TY, Wang SK. A Review of Organic Rankine Cycles (ORCs) for the Recovery of Low-Grade Waste Heat. Energy 1996; 22: 661-7.

[5] Maloney JD, Robertson RC. Thermodynamic Study of Ammonia-water Power Cycles. Oak Ridge National Laboratory report. 1953; CF-53-8-43. Oak Ridge, TN.

[6] Ibrahim OM, Klein S. Absorption Power Cycles. Energy 1996; 21: 21-7.

[7] Rogdakis ED, Antonopoulos KA. A High Efficiency $\mathrm{NH}_{3} / \mathrm{H}_{2} \mathrm{O}$ Absorption Power Cycle. Heat Recovery Systems and CHP 1991; 11: 263-75.

[8] Kalina AI. Combined Cycle System with Novel Bottoming Cycle. Journal of Engineering for Gas Turbines and Power 1984; 106: 737-42.

[9] Singh OK, Kaushik SC. Energy and Exergy Analysis and Optimization of Kalina Cycle Coupled with a Coal Fired Steam Power Plant. Applied Thermal Engineering 2013; 51: 787-800.

[10] Ogriseck S. Integration of Kalina cycle in a combined heat and power plant, a case study. Applied Thermal Engineering 2009; 29: 2843-8.

[11] Bombarda P, Invernizzi CM, Pietra C. Heat recovery from Diesel engines: A thermodynamic comparison between Kalina and ORC cycles. Applied Thermal Engineering 2010; 30: 212-9.

[12] DiPippo R. Second Law assessment of binary plants generating power from low-temperature geothermal fluids. Geothermics 2004; 33: 565-86.

[13] Zhang N, Lior N. Development of a Novel Combined Absorption Cycle for Power Generation and Refrigeration. Journal of Energy Resources Technology 2007; 129: 25465.

[14] Goswami DY. Solar Thermal Power Technology: Present Status and Ideas for the Future. Energy Sources 1998; 20:137-45.

[15] Xu F, Goswami DY, Bhagwat SS. A Combined Power/Cooling Cycle. Energy 2000: 25: 233-46.

[16] Vijayaraghavan S, Goswami DY. On Evaluating Efficiency of a Combined Power and Cooling Cycle. Journal of Energy Resources Technology 2003; 125: 2217.

[17] Hasan AA, Goswami DY. Exergy Analysis of a Combined Power and Refrigeration Thermodynamic Cycle Driven by 
a Solar Heat Source. Journal of Solar Energy Engineering 2003; 125: 55-60.

[18] Lu SG, Goswami DY. Optimization of a novel combined power/refrigeration thermodynamic cycle.ASME Journal of Solar Energy Engineering 2003; 125: 212-7.

[19] Tamm G, Goswami DY, Lu SG, Hasan AA. Novel combined power and cooling thermodynamic cycle for low temperature heat sources. Part 1: Theoretical investigation. Journal of Solar Energy Engineering 2003; 125: $218-22$.

[20] Tamm G, Goswami DY. Novel combined power and cooling thermodynamic cycle for low temperature heat sources. Part 2: Experimental investigation. Journal of Solar Energy Engineering 2003; 125: 223-9.

[21] Martin C, Goswami DY. Effectiveness of cooling production with a combined power and cooling thermodynamic cycle. Applied Thermal Engineering 2006; 26: 576-82.

[22] Sadrameli SM, Goswami DY. Optimum operating conditions for a combined power and cooling thermodynamic cycle. Applied Energy 2007; 84: 254-65.

[23] Padilla RV, Demirkay G, Goswami DY, Stefanakos E, Rahman MM. Analysis of power and cooling cogeneration using ammonia-water mixture. Energy 2010; 35: 4649-57.

[24] Amano Y, Suzuki T, Hashizume T, Akaiba M, Tanzawa Y, Usui A. A hybrid power generation and refrigeration cycle with ammonia-water mixture. Proceedings of International Joint Power Generation Conference; 2000 July 23-26; Florida, USA. IJPGC2000-15058.

[25] Takeshita K, Amano Y. Demonstration of a Hybrid Power and Refrigeration Ammonia-Water Cycle. Proceedings of GT2006, ASME Turbo Expo 2006: Power for Land, Sea and Air; 2006 May 8-11; Barcelona, Spain. GT200691319.

[26] Zheng DX, Chen B, Qi Y, Jin HG. Thermodynamic Analysis of a Novel Absorption Power/Cooling Combined Cycle. Applied Energy 2006; 83: 311-23.

[27] Zhang N, Cai RX, Lior N. A novel ammonia-water cycle for power and refrigeration cogeneration. Proceedings of the ASME Advanced Energy Systems Division, 2004; 183-96.

[28] Zhang N, Lior N. Methodology for Thermal Design of Novel Combined Refrigeration/Power Binary Fluid Systems. International Journal of Refrigeration 2007; 30: 1072-85.

[29] Liu M, Zhang N. Proposal and Analysis of a Novel Ammonia-Water Cycle for Power and Refrigeration Cogeneration. Energy 2007; 32: 961-70.

[30] Liu M. Study on Integrated Power/Refrigeration System and Low $\mathrm{CO}_{2}$ Emission Power System with LNG Cryogenic Energy Utilization [Dissertation]. Beijing:
Graduate School of the Chinese Academy of Sciences; 2008. Chinese.

[31] Wang JF, Dai YP, Gao L. Parametric Analysis and Optimization for A Combined Power and Refrigeration Cycle. Applied Energy 2008; 85: 1071-85.

[32] Wang JF, Dai YP, Zhang TY, Ma SL. Parametric Analysis for A New Combined Power and Ejector-Absorption Refrigeration Cycle. Energy 2009; 34: 1587-93.

[33] Jawahar CP, Saravanan R, Bruno JC, Coronas A. Simulation studies on gax based Kalina cycle for both power and cooling applications. Applied Thermal Engineering 2013; 50: 1522-9.

[34] Angrisani G, Roselli C, Sasso M. Distributed microtrigeneration systems. Prog Energy Combust Sci 2012; 38; 502-21.

[35] Feng X, Cai YN, Qian LL. A new performance criterion for cogeneration system. Energy Convers Manage 1998; 39; 1607-9.

[36] Aspen Plus ${ }^{\circledR}$, Aspen Technology, Inc., version 11.1, http://www.aspentech.com/.

[37] International Institute of Refrigeration, 1994, "Thermodynamic and Physical Properties NH3-H2O."

[38] Fernández-Seara J, Sieres J. The Importance of the Ammonia Purification Process in Ammonia-Water Absorption Systems. Energy Conversion and Management 2006; 47: 1975-87. 